Engy Salah Tawfeek Saleh

\title{
Magical Realism: A Step Further Towards Eco-Feminism With Special Reference to Marquez's Innocent Erendira
}

\author{
Engy Salah Tawfeek Saleh
}

Lecturer- Damietta Faculty of Arts

\begin{abstract}
:
This paper aims at investigating the contribution of magical realism as a narrative mode to the thematic critical content of eco-feminism as a current influential literary domain. Eco-feminism is a thematic critical theory in the sense that it tackles themes and ideas more than techniques and structure. In comparison to formalism, structuralism and post-structuralism, eco-feminism proves to be more thematically oriented. For this reason, it is the interest of this paper to work on extending the domain of this theory to embrace magical realism as a narrative mode that defamiliarizes its thematic definition. The paper is based on proposing that between magical realism and eco-feminism, there is a relationship that springs from the similarity between them, in addition to the significance attributed to eco-feminism when enhanced by magical realism as a mode of narration. This brings into concern both 'duality' and 'defocalization' as leading terms that knot both magical realism and ecofeminism to postmodernism as a basic context of reference, bringing the theme of accepting the 'Other' into the scene. Literary cross references are to be made to Garcia Marquez's short novel The Incredible and Sad Tale of Innocent Erendira and Her Heartless Grandmother. This short novel is used to explain and show how magical realism, through the theme of avenging abuse, has enhanced the eco-feminist reading that is based here on naturalizing woman as a step towards feminizing Nature in the text.
\end{abstract}

Key Words:

Magical realism- defocalization- Ecofeminism- feminizing Nature- Marquez's Innocent Erendira

This paper aims at investigating the contribution of magical realism as a narrative mode to the thematic critical content of eco-feminism as a current influential literary domain. Eco-feminism is a thematic critical theory in the sense that it tackles themes and ideas more than techniques and structure. In comparison to formalism, structuralism and poststructuralism, eco-feminism proves to be more thematically oriented. For this reason, it is the interest of this paper to work on extending the domain of this theory to embrace magical realism as a narrative mode that defamiliarizes its thematic definition. Many critics, like Jean-Pierre Durix, Stephen Slemon, Christopher Warnes and others worked on linking magical realism to post-colonialism. This has been mainly done through analyzing literary works more than resting on tackling the main 
thematic pillars that would link post-colonialism as a literary theory to magical realism. Again, a literary link has been held between feminism and magical realism and evolved in magical feminism, but has not approached eco-feminism. The paper proposes that between magical realism and eco-feminism, there is a relationship that springs from the similarity between them, in addition to the significance attributed to ecofeminism when enhanced by magical realism as a mode of narration. This brings into concern both 'duality' and 'defocalization' as leading terms that knot both magical realism and eco-feminism to postmodernism as a basic context of reference, bringing the theme of accepting the 'Other' into the scene. The part of discussion allotted to magical realism is longer than that allotted to eco-feminism since it is the aim of the paper to see into the significance of embroidering magical realism into the very artistic fabric of eco-feminism as a settled theory. For the sake of analysis and explanation, literary cross references are to be made to Garcia Marquez's short novel The Incredible and Sad Tale of Innocent Erendira and Her Heartless Grandmother (1972) ${ }^{1}$. This short novel is used to explain and show how magical realism, through the theme of avenging abuse, has enhanced the eco-feminist reading that is based here on naturalizing woman as a step towards feminizing nature in the text. The paper does not intend to prove that the novel has elements of magical realism and a potential for an eco-feminist reading as much as it uses that novel to shed light on the theories and how they work together. This necessitates giving a due theoretical introduction to what magical realism and eco-feminism are.

Magical realism as a term was first used by Franz Roh in 1925 in art before it was introduced to literature by the Italian writer Massimo Bontempelli. The term has become popular in English with the publication of Gabrial Garcia Marquez's One Hundred Years of Solitude in 1970 (S. Thamarana 264). This makes Gabriel Garcia Marquez (19272014), the Caribbean writer who was awarded the Nobel Prize in 1982, a representative leading figure of magical realism. Generally speaking, magical realism is a narrative mode that is based on the discrepancy held between what is 'illogical' and what is 'logical'. It is not a technique as much as it is a mode since it results in dragging the readers into a certain mode that destabilizes their traditional thoughts. It is not a mere tool; it is a whole state instead. Magical Realism is "a mode [that] operates as discourse, irrespective of specific thematic content" (Faris 3). Thus, it cannot be a genre in its own way since it can be held in romance, science fiction, historical texts, etc. Generally speaking, it is a narrative mode 


\section{Engy Salah Tawfeek Saleh}

that rests on bringing the impossible to the arena of the real, though illogical, creating a hybrid entity of experiential existence. Magical realism works through a 'decentering ideology' that feeds almost all needs of minorities, e.g. class minority, race minority, gender minority, age minority, etc. representing a "decolonizing agent" (Faris 1); everything is, thus, driven out of its center to rule independently. Aristocracy, European, man, elders are no more the centers of discourse. In this regard, the postcolonial critic Brenda Cooper writes that magical realism is against fundamentalism since "it is at odds with racism, ethnicity and the quest for tap roots, origins and homogeneity" (22). In other words, in the core of magical realism, all binary oppositions are deconstructed and held freely as complementary. Nothing is purely composed of one thing; the origin becomes the hybridity and multiplicity more than the singularity and individuality.

The meaning and significance of magical realism is held tightly clear in the sense of duality that springs from the very opposition in the meaning of the two words composing it. Defined to be a "term referring to fiction that integrates realistic elements with supernatural or fantastic experiences." (E. Quinn 252), magical realism is made up of two words: 'magical' and 'realism'. The first word actually comes ushering the second in a sort of defiant announcement of the fact that the introduced term, in its whole, challenges the term 'realism'. Here, it is worth noting that the word magical implies "any extraordinary occurrence and particularly to anything spiritual or unaccountable by rational science.... but does not include the magic as it is found in a magic show." (M. Bowers 19). In magic shows, it is important that the audience be brought into the illusion that something abnormal is going to happen while in magical realism, the abnormality is woven up as an inseparable tissue of the real itself. All the time, even when the magical is foregrounded, the real is lying in the background giving essence and coloring the meaning intended to be conveyed.

The other part of the term 'magical realism' is related to realism, which is generally defined as "a term covering a broad range of views centered on the attempt to depict life as it is usually experienced, without recourse to miraculous events, larger-than-life characters, or supernatural intervention." (Quinn 353). As a result, in magical realism, realism exists, but with some features that defy it, like the supernatural or the occult. That is why 'magical realism' has come to relate with surrealism as a movement that proposed the "inadequacy of art that attempted to realistically present the exterior and material world without expressing the influence of the inner-life on it" (Bowers 11). In surrealism, the 
elements that make up the painting are all real but represented in such a deformed way that gets them out of the materialistic physical world people are used to. Both of magical realism and surrealism, thus, worked at reconciling paradoxes and contradictory realms of existence into one complementary whole that serves a true representation and an identification of the non-pragmatic aspects of reality. Consequently, it is clear that implied in 'magical realism' is a sense of duality that is magnified artistically for the sake of thematic manipulation.

The duality held in the term is an invitation to accept differences. Thus, instead of changing what seems different, one should recondition $\mathrm{him} / \mathrm{herself}$ to suit or to fit into a differing and changing environment. Consequently, the duality inherited in the very core of magical realism opens it up for the readers to decompose reality in order to recompose it anew. In other words, without a realistic setting, magical realism cannot apply, and without a fantastic endowment, it does not exist. Consequently, the 'duality' here breeds for hybridity and multiplication. Differences are invested to grow and expand, but under the condition that they are first to be identified and met seriously. It is noteworthy that such differences are sometimes assimilated to exist simultaneously within the same person so that it is intended to prove that differences can co-exist, but need to be incorporated peacefully.

In The Incredible and Sad Tale of Innocent Erendira and Her Heartless Grandmother (1972), this duality is very clear. The grandmother is interiorly oppressed and victimized, but exteriorly oppressing and victimizing. She is the grandmother, who is supposed to be caring and loving. However, she is also the woman who sells the body of her granddaughter to who pays more. Erendira herself is interiorly oppressed and victimized, but exteriorly caring and loving. She is the granddaughter, who is serving her aging grandmother. However, she turns to be the plotter for the murder of this grandmother. Erendira, again, is the loving girl who falls in love for the first time with Ulisses, but who pushes him to commit a crime. Simultaneously, she is both the beloved and the disposing woman who flies away with the gold leaving her lover to face the consequences of his murder. The reader does not find her/ himself unbelieving or shocked in both cases. The dual co-existence of two opposing entities is what matters. They co-exist, but they do not unite in one. For the sake of influence, they must be kept two entities in order 


\section{Engy Salah Tawfeek Saleh}

for the whole effect to emerge. The need, thus, is for a sort of reconciliation that would be based on a compromise.

In Innocent Erendira, Marquez is keen on not introducing any 'incredible' incident until the first third of the story is over. He first sets a realistic background that is concerned with a young girl and her grandmother inhabiting a big house in the midst of the desert with marble statues and huge clocks that take six hours to be wined. Then the readers are swayed with sympathy from the very beginning towards this young girl who is responsible for everything in such a house. She is even responsible for feeding, bathing and caring for her grandmother, who does not show any merciful feelings towards her. Some incredible hints are scattered here and there, but are not yet fantastic enough to be taken into consideration, like the "the goats [which] committed suicide from desolation when the wind of misfortune blew" (Marquez 546). This could be easily interpreted metaphorically to show the hardships of life in such a place. Thus, magical realism depends, in the first place, on furnishing the work of art with a plethora of realistic events and descriptions that would convince the readers that this is the life they know. This comes in contradiction to Kafka, for example, who begins his novella Metamorphosis (1915) with: "As Gregor Samsa woke one morning from uneasy dreams he found himself transformed in his bed into a gigantic insect" (F. Kafka 335). Kafka makes the fantastic his first point of priority, but Marques sets the real bare before it springs into the unreal to prove his point. Marques starts his novel with the real before he gets the readers to experience the unreal or the illogical. It is to be noted here that the idea of prostitution, that Erendira is driven into, itself supports this realistic framework of the novel that is set in a time in which Colombia was suffering from child prostitution.

Through a combination of folklore, mythology and the fantastic, magical realism does not defy realism as much as it complements it through filling the gaps. As a mode of narration that rests on building up unreal blocks within the overall realistic matrix it introduces, magical realism is capable of saying out what has been kept unspoken within the domain of realism. Here, Wendy Faris uses a very effective metaphor to make the relationship between the two words composing the term 'magical realism' clearer. He states that magical realism "is like a grain of sand in the oyster of ... realism. And because it disrupts reading habits, that irreducible grain increases the participation of readers, contributing to the postmodern proliferation of writerly texts, texts co-created by their readers" (8-9). The metaphor, here, is really catching because an oyster 
would never form this invaluable gemstone called pearls if they were not irritated by an outsider, represented here in the fantastic element. Again, it is worth noting that the pearl is the only gemstone that is used in the same shape it is formed in i.e. it is not cut or polished as other gemstones. Like the pearl, which is very distinguished, so is the truth readers are faced with when they are put into that mode created by magical realism. Truth, here, does not need that effort exerted by other realist writers using other modes of writing, so that they can introduce truth well-cut and polished.

The process here is closer to 'nucleation', which means that the foreign object is willingly and intentionally inserted inside the oyster so that it starts to behave defensively and form this hard crystalized object in order to protect itself. The same is the fantastic or unreal element. Such elements are very artistically and precisely spin into the soft texture of the work, so that it does not seem artificial, yet it must seem a real outsider in order to accomplish the mission. In other words, the magical makes the readers look more seriously and thoroughly into the realism supposedly introduced in the novels to see things as they 'are' not as they 'seem to be', yet they should not feel that the element introduced is fake, because at that time the truth intended will not be formed; the oyster will sense the fakeness and will not form the pearl.

Magical Realism defies the center by shifting the scene away from the unfavorable real, which is taken for granted and surrendered to, towards the impossible that shakes the ground and introduces all that lies in the peripheries. It places under the spot all that has been marginalized and degraded, and places it within a new intellectual context of reference. Actually, it "combines realism and the fantastic so that the marvelous seems to grow organically within the ordinary, blurring the distinction between them" (Faris 2). In this context, nothing is strange to be excluded, but is different enough to enrich the tissue and enhance the growth of something else. What is distinguished in magical realism is that the fantastic element is not questioned or even scrutinized.

In Marquez's Innocent Erendira, the grandmother asks Ulises about his wings and he normally answers, "The one who had wings was my grandfather" (G. Marquez 554). Ulises is not surprised; he approaches the question as if she is asking him about something that he is well acquainted with. Another instance that explains the non-questionability of the unreal comes when Ulises's mother explains his abnormal ability of 


\section{Engy Salah Tawfeek Saleh}

changing the color of glass upon touching it as something normal for those who fall in love. He has also been unable to eat bread because he's in love "people who are lovesick can't eat bread" (Marquez 561). Consequently, all that seems surprising proves to be an original part of real life. Here, one cannot separate the realistic from the unrealistic; it seems as if they grow interdependently. As Michael Woods expresses this, magical realism implies "that the world is a fabrication and full of delirious improbabilities but, alas, still real enough; that the imagination is nearly always right. (Wood 3). In other words, the improbabilities held within the framework of magical realism are the source of meaning in the text.

Tracing magical realism theoretically, one cannot do without paying attention to the narrative point of view. Here, it is important to discuss Faris's term of "defocalization" as a distinctive feature of magical realism. Within a postmodern frame of reference, magical realism has been said to be "a remystification of narrative in the West" (Faris 3). It introduces a new narrative method of literary representation than that of the traditional mainstream literature. Traditionally, focalization, as a term, has been given to the way individualized voices are dealt with in a certain narrative. Here comes 'defocalization' to differ as it depends on a technique that is keen on depriving the fantastic element of any focal point of reference that can be neither trusted nor distrusted. The senses, here, are unable to carry the load, and the narrative voice is unspecified. Thus, there appears a necessity that the narrative, with magical realism, be "defocalized" (Faris 3), so that no one character bears the responsibility. This defocalization corresponds to Gerald Prince's "nonfocalized" or "zero focalized" narrative mode that refers back to the omniscient narrator. Faris molded his term 'defocalization' to be exclusively identified with magical realism so as to satisfy its needs and suit its very distinct nature. The fantastic hues in the text are not restricted to one character or one incident. Faris proposes that defocalization is a typical narrative point of view in magical realist texts since the perspective it addresses is not to be told as much as it is experienced in its own turn. In another way, the term is intended to show how magical realism "constitutes a particular way of focalizing as a genre, irrespective of the particular perspectives and narrators in individual texts." (Faris 43). Consequently, 'defocalization' has become a distinguishing feature of magical realism.

In Innocent Erendira, even the mayor is involved. He is originally a military man whom the grandmother finds "in the courtyard of his home, his chest bare, shooting with an army rifle at a dark and solitary cloud in 
the burning sky. He was trying to perforate it to bring on rain, and his shots were furious and useless" (Marquez 557). When he tells the grandmother that he cannot do anything to get her granddaughter after she was kidnapped by a missionary group of priests, and is asked why he is the mayor then, he answers immediately, "To make it rain" (Marquez 557). The fantastic element first comes into the scene through zerofocalization because it is presented through the omniscient narrator before the mayor admits it himself. If it was first presented through the mayor, the readers would doubt it because maybe the mayor is insane, or he might be kidding the grandmother. Thus, defocalization comes to put the fantastic into a normalized domain of representation so that it complements the real scene presented.

The last example of the fantastically, yet realistically, formulated elements in the novel is how the Grandmother is physically introduced. The grotesqueness of the Grandmother figure lends a lot to the magical realism mode of narration and ushers in the theme of abuse as a necessary component for the eco-feminist reading being discussed later. Her deformed physical shape denotes her mercilessness and brutal nature. Actually, her grotesqueness gives her an additional authority over Erendira. The girl is afraid of her, but has nothing to do but to surrender. The Grandmother, who is never given a name, is the huge "white whale" whom Erendira takes two hours to get ready after bathing just to look like a "larger than life-size doll" (Marquez 545). Even after falling asleep, the mother goes on giving orders to poor Erendira to "give the graves some water" (Marquez 547). All the time, the Grandmother is described not attacked or criticized; and this is one of the features of magical realism i.e. not to doubt anything. Erendira continues to do what the grandmother orders though she is sure that the woman is asleep just because she knows that her Grandmother "can dream things" (563). She sensed the approach of death just after Erendira and Ulises planned to kill her, saying, "Death is on the loose tonight" (564), and even after being poisoned, she does not die; she has just lost hair. After Ulises' last attempt at killing her, the Grandmother "Huge, monolithic, roaring with pain and rage... grasped Ulises' body. Her arms, her legs, even her hairless skull were green with blood" (Marquez 574). The Grandmother in Innocent Erendira is a clear grotesque female representation that could be traced within the whole context of eco-feminism.

Eco-feminism is a branch of literary criticism that has come out of a merge between ecology and feminism. The term was first coined by Francoise d'Eaubonne in Feminism or Death (1974) wherein she draws a 
direct relationship between the global over-population, that exhausts the planet, and the patriarchal denial of women to control their own bodies. However, eco-feminism joined the academic domain only in the middle of the 1980s with authors like Salleh in 1984, Plumwood in 1986 and Warren in 1987. Eco-feminism falls in three main divisions: cultural/spiritual ecofeminism that traces the natural link between woman and 'Mother Earth' (Suasan Griffin and Starhawk), constructivist ecofeminism that negates this essentialist relationship denying any natural relationship between women and earth (Simone de Beauvoir and Sherry B. Ortner), and socialist ecofeminism that drives an intermediate place between the cultural and the constructivist (Karen Warren and Maria Mies). Eco-feminism, like all the other genres of feminism, has been brought into the realm of literature to trace how the oneness of women and nature is portrayed in literary works (Buell 2005; Carr 2000; Gaard 2010; Gaard and Murphy 1998; Murphy 1995).

Deep within its critical framework, ecofeminism is comprised as "an attempt to outline a new utopian horizon, addressing the environmental issue from the categories of patriarchy, androcentrism, care, sexism and gender" (Puleo 30). Within the framework of ecofeminism is held the proposition that both women and nature have been subjected to a process of marginalization that kept them inferior and oppressed; nature against culture and woman against man. In eco-feminism, there is an authentic similarity between nature and woman in that "men were instructed to protect and preserve humanity and the environment through the process of multiplication, involving both the seminal implantation of their seed in the wombs of women as well as the natural seeding of the soil, both of whom were required to be passive reservoirs" (D. Shober 2). Man was allowed to transgress the limits with nature, hailing the advent of industrialization, and the limits with woman, hailing the duty of protection and superiority.

Eco-feminism looks up to an ideal world which is based on interconnectedness among all its inhabitants, whether human or nonhuman. Stability would never exist if one of those inhabitants exceeded to impose influence and control over the others. This is asserted by Karen Warren who states in Ecofeminist Philosophy that eco-feminists "claim that there are important connections between the unjustified dominations of women, people of color, children, and the poor and the unjustified domination of nature." (1). All these 'dominations' imply a relationship of domination/subordination that always controls the scene. Consequently, eco-feminism calls for the involvement of all the 'Others' in one healing crucible that would guarantee them safe existence. The 'Other' is no more unneeded or discarded, but is contained and glorified 
as a part of the whole self. Here springs the issue of getting eco-feminism in direct relation to Romanticism as a genuine stimulator. Actually, while Romanticism brings in through nature a subjective and individualist vision of the self, eco-feminism brings in an objective universal vision of the self, being part of one whole. While Romanticism regards nature as a mirror reflecting what is going on inside, eco-feminism looks at Nature as part and parcel of one great entity which is no more subjective as much as it is universal. This asserts the main rubric under which eco-feminism works i.e. calling for totality.

Eco-feminism is based on a double-way representation of woman and nature in the sense that it gives nature feminine attributes, on the one hand, and endows woman with hues of naturalistic features, on the other. Generally, a certain topic is given the "feminine" attribute when "an understanding of which helps one understand the oppression, subordination, or domination of women" (K. Warren 1). Held within the same context, one could propose that a certain topic is given the 'naturalistic' attribute when it works on comprehending and analyzing the injustice nature is subjected to. This results in a reciprocal relationship being delineated with much care and accuracy between women and nature, together with all the oppressed and victimized, on the one hand, and the patriarchal figure, together with all the oppressors and the victimizers, on the other.

In Innocent Erendira, this double-way representation can be easily traced in a way that deepens the theme of avenging injustice on the hands of the oppressed 'Other'. This 'Other' is literally woman, and is metaphorically nature. In the novel, it is easy to sense the persistent presence of nature in most of the scenes. Nature is brought extensively into the novel to the extent that the readers can see it moving with the characters introduced. Marquez succeeded in visualizing the reciprocal relationship between Erendira and nature, so that readers can see Erendira running "and she was swallowed up in the shadows of the wind where the owl was calling" (Marquez 565). Nature and Erendira have spiritually become one, but still physically separated. Now, they embrace each other as if finally met physically after a long time of separation. Nature always exists in Erendira's company witnessing "the wind of her misfortune [as it] began to blow" (Marquez 545). Marquez starts the novel with Erendira showing naturalistic affiliation, and he ends the novel with her dissolving completely into nature, into the "never-ending sunsets" (Marquez 575). 


\section{Engy Salah Tawfeek Saleh}

In tracing how Nature is embodied in Erendira, one could easily find a link between the young girl in the beginning and at the end of the novel. Erendira is introduced as very naïve and kind-hearted, but after long abuse and injustice, she turns to be experienced as she "acquired all the maturing of an older person" (Marquez 574), and she leaves quietly after her grandmother is killed. Like nature, which is losing every day part of its youth, is young Erendira who loses every day part of her innocence and natural beauty. In a very indicative scene, the grandmother starts to beautify her putting tons of make-up on her innocent face. Though she sees that the make-up makes her "look awful" (Marquez 551), she goes on in 'polluting' her face, saying, "but it's better that way, men are quite stupid when it comes to female matters" (Marquez 551). Like Erendira, nature is 'polluted' by all facets of civilization and technology that seem to be an advance, yet prove to be "awful" in all respects. Like men who are "stupid" to the extent that they are deceived by Erendira's makeup, all humans turn to be stupid to be deceived by the seeming beauty of nature which they are polluting. Like makeup is all technological devices that aim at beautifying nature, but what they really do is pollution.

On speech level, and like nature, Erendira is always silent. She "never spoke except when it was unavoidable" (Marquez 545). She keeps silent and digresses into sleep while working in the house just to escape revolting against her grandmother because she is the maternal figure from her she is supposed to derive an identifying self-image. In one of the scenes portraying Erendira while working at the house, Marquez writes, "she closed her eyes, opened them again with an unfatigued expression... she was working as she slept" (Marquez 546). Like Nature, she is always trying to ignore this oppressing context of living; she escapes into a sleeping mode in which the readers never encounter any dreams. She is patient and over-bearing until she suddenly bursts. Nature keeps benevolent with all human irresponsible doings and actions, but one day it will violently answer back, even if this implies destroying itself to avenge.

The identification between Erendira and Nature held here as a necessary assumption for an eco-feminist reading of Innocent Erendira springs out of that theme of abuse that develops inevitably into that of revenge. The abuse/revenge theme here is found to be working on three levels: manwoman and reversibly woman-man; woman (Grandmother)-woman (Erendira) and reversibly woman (Erendira)- woman (Grandmother); and the self (Erendira). The man-woman abuse goes back to have roots in the Grandmother's past life. It is very clear that she led a difficult life that has 
made her convinced that the only sense of safety is that a woman "won't be left to the mercy of men" (Marquez 568). Again, Marquez is keen on portraying how much the Grandmother was oppressed through the artistic device of dreams through which she "floated through the swamps of the past" (Marquez 545). She was a prostitute in her youth before getting to marry her husband Amadis, who "transplanted her forever in the impunity of the desert" (Marquez 546). In addition, this level works also well on Erendira herself with the village storekeeper who agreed to have her only after "he had some calculations of what she was worth" (Marquez 548), and many other men whom her Grandmother sold her to. The revenge comes symbolized in Erendira leaving Ulises after he has killed the Grandmother and escaping with the gold she took. Watching her leaving, Ulises "made a last effort to chase her, calling her with painful shouts that were no longer those of a lover but of a son... weeping from solitude and fear" (Marquez 575).

The second level i.e. woman-woman abuse, is restricted to the relationship between Erendira and her Grandmother who has made use of her to replace the servants she fired because she could not afford them after her husband's death. Referring to the problem of child prostitution in Colombia, Marquez introduces the Grandmother who puts her granddaughter on the way for the most degrading and humiliating thing she would ever do i.e. prostitution. After the house is destroyed by the fire, she throws all the responsibility on Erendira telling her, "Life won't be long enough for you to pay me back for this mishap" (Marquez 548). She takes the girl's submission for granted till Erendira suddenly revolts and plots to kill her on the hands of Ulises. Actually, the color of the blood that comes out of the Grandmother's body, after she is killed by Ulises, is an explanation of how she dared doing this with her granddaughter. The "oily blood, shiny and green, just like mint honey" (Marquez 574) is the only force that frees Erendira of her Grandmother's spell. The blood is not red or crimson, but is green; it is logical then why the Grandmother usurps her all the time. The blood is green because this is the only color that would water the hunger of green nature for revenge.

All the time, Erendira "had to fight off the anger of the wind, which had become unbearable, but didn't have the slightest feeling that it was the wind of her misfortune" (Marquez 546). She abused herself by surrendering to her Grandmother to the extent of internalizing such an abuse as a normalized state of obedience and gratitude. Like Nature, she 


\section{Engy Salah Tawfeek Saleh}

over-bears and within the process, she gets merciless to get the initiative and manipulate her lover to kill the Grandmother once and again. In killing her grandmother, Erendira is killing herself and destroying her life in which she has nobody except for the Grandmother and Ulises. She gives them up simultaneously and in the process she fades as she kept on "running with the gold vest beyond the arid winds and the never-ending sunsets and she was never heard of again nor was the slightest trace of her misfortune ever found" (Marquez 575). Like Erendira, Nature is destroying itself in punishing the humans who misused and polluted it. Global warming is evidence on such an attempt at punishment through self-destruction.

In The Death of Nature, Carolyn Merchant states that there are two main versions of nature: the decent feminized version and the modern mechanized one. The first evolves from the organic theory rooted in the "identification of nature, especially the earth, with a nurturing mother."(2). However, with the advent of industrialization, nature lost its privilege and became subordinated to power and mechanization. The grandmother in Innocent Erendira has the seeds of both versions. She is the grandmother who is supposed by name to be the kind and caring mother for Erendira after the death of her father and mother. She is not a patriarchal figure, and she is not a stranger who may be expected to hurt the little girl. In such a sense, she calls in the first version of nature. However, this grandmother is introduced as a merely materialistic person who sells her granddaughter's body for the sake of money caring nothing for her future or for her feelings. In this case, the grandmother represents the second version of nature that has been deprived of its innate sense of giving, being upgraded to serve only the needs of modern materialistic life. Tanritanir proposes that the universe is based on a natural system that keeps each one intact in his/her own place. That is why "People who want to spoil this formation are against the rules of the nature" (216). Therefore, she has violated the natural rule of things that the first version implies, and, thus, must be punished.

Eco-feminism is deeply located in Donna Haraway's term "situated knowledges" which "require that the object of knowledge be pictured as an actor and agent, not as a screen or a ground or a resource, never finally as slave to the master that closes off the dialectic in his unique agency and his authorship of 'objective knowledge" (592). The oppressor is the master who closes the circle of signification to include only his own signifiers and proposes this to be the 'objective' referential point of knowledge for all others. Here lies the core of eco-feminism; inducing 
agency into the very essential makeup of an entity and urging the upper hand controlling other to accept it. Implied here is the fact that both woman and nature need to be freed from the oppression that they are hindered by to become more subjects than objects. It is not to be ignored that Erendira, by the end of the novel, is the one who dominates by manipulating a male figure, Ulises, to kill the grandmother, a female figure, more than once. The point here is that if not incorporated into a positive agent position, an oppressed is always directed towards performing a negative one that may involve violence towards the self or the others. Again, the open-endedness of the novel calls for and supports the eco-feminist reading of the novel as it clearly links Erendira and Nature. It serves to technically represent the non-expectancy of the destruction nature may lead on people and itself if things remain as they are, pushing it to the verge of self-destruction.

Both magical realism and eco-feminism rest on the notion of hybridity that is inherited in the dual presence of two different entities in their names. Both are comprised of two terms that are held together to form a new entity; 'magical' and 'realism' in the case of magical realism, and 'ecology' and 'feminism' in the case of eco-feminism. In addition, they both spring form an original existence that makes logical the escalation in each one's thematic content to enhance the other; realism in the case of magical realism, and feminism in the case of eco-feminism. Furthermore, they both sprout out from a postmodern trend towards accepting the other, however different or even opposite it/s/he is. Magical realism has, thus, proven through the discussion to be a step further towards consolidating the effect and influence of eco-feminism as a trend of thought that is mainly based on linking not only Nature to women, but on interrelating all people, creatures and entities in the universe together.

Heading more specifically towards the oppressed, eco-feminism finds in magical realism a genuine supporter and agent that speaks out, through the discrepancy held between the two words it is composed of, all about the illogicality of many political and social practices. All those who have been marginalized need to be spoken about from a new perspective that gives them their due right. Because Eco-feminism is based on finding a link between a human and a non-human entity i.e. woman and Nature, and that it, thus, needs a narrative mode that links speech with nonspeech, there springs the significance of mating it with magical realism. Magical realism comes to be a typical mode of narration to be used in all those texts that aim at hailing interconnectedness among all elements of 
the universe as it defies the real by the organic merge of the realistic with the fantastic.

Magical realism as previously stated depends on the realistic background or setting that is organically induced with the fantastic element, so that no argument or denial would spoil the effect. Here, its role intensifies the thematic make-up of eco-feminism taking it away from the argumentative and debating arena. Magical realism helps in introducing eco-feminism as a critical lens of literary appreciation and analysis that needs extending the effect of inter-subjectivity, and internalizing it so that it comes to be taken for granted. In Ercan Gurova's words, "Marquez may imply that in circumstances where there are no social safety nets or institutions to protect vulnerable people, the only real rescuer and liberater is the magic" (1212). All institutions fail to help Erendira or save her. The missionaries who took her to save her form prostitution fail to protect her, and the mayor, who represents the political and social authority, comes himself to help the grandmother restore Erendira to her dominance.

Again, engraved into the very nature of magical realism is that indefinite narrative voice when it comes to the fantastic element. This trait, actually, hits strongly and effectively on the thematic core of eco-feminism which is trying to give through plurality a unified universal voice that is not restricted to a one-sided patriarchal, human, or even political existence. Faris asserts this when he states that "the multivocal and defocalized narrative of magical realism, which bridges the diverse worlds of realism and fantasy, is double-voiced in the way female voices have been, integrating both a dominant and a muted mode in a given text" (4). This result satisfies the main goal of the research as it defends and presents a particular version of eco-feminism that is enhanced by the introduction of magical realism into the core of its artistic texture.

In Innocent Erendira, the eco-feminist undercurrent is driven in color when introduced within the contextual framework of magical realism. Feminizing nature and naturalizing women are rendered normalized when measured against the many examples and hints of magical realism in the text. Linking magical realism as a narrative mode to eco-feminism explains why women characters have been, to use Faris's term, "narrative enablers" in works written by male magical realists like Garcia Marquez. Through an eco-feminist reading that is based mainly on magical realism as a narrative mode and tool of analysis, Innocent Erendira is read allegorically setting the main female character Erendira as an extended metaphor to Nature itself. On the theoretical level, duality and defocalization are employed, together with many other literary devices like silence, the grotesqueness of the Grandmother, feminizing Nature 
and naturalizing women within the whole context of the thematic framework of avenging abuse to address magical realism as a significant term in complementing ecofeminism. All these elements come to serve perfect tools to link the two main pillars of the paper together proving magical realism as an enriching and enhancing artistic device that help getting eco-feminism beyond the borders of its thematic orientation. Actually, there lies in the novel an extended potential for critical readings. The special shift in the setting form the desert to the town and back is an interesting potential for a geo-critical reading of the novel.

\section{Notes:}

(1) Garcia Marquez's The Incredible and Sad Tale of Innocent Erendira and Her Heartless Grandmother is the story of the young fourteen-year old Erendira who is physically abused by her grandmother to clean, cook and serve her, before she is driven to make up for a fire that destroys their house by selling her body to whoever could pay a price. The 'merciless grandmother', as mentioned by Marquez in the title, convinces herself, as well as the poor young Erendira that she is responsible for the fire and that, consequently, she is to pay her the money that the house is worth of. Because Erendira does not own anything except her body, she is obliged to be a prostitute for any man who has money to pay. By the end of the novel, Erendira asks and pushes one of her clients, Ulises, to kill her grandmother, and she gets the gold her grandmother has been saving, and runs away alone without Ulises. The novel is left open-ended, without any reference to what will come of Erendira after running away. 


\section{Works Cited:}

Bowers, Maggie Ann. Magic(al) Realism: The New Critical Idiom. New York: Routledge, 2004.

Cooper, Brenda. Magical Realism in West African Fiction: Seeing with a Third Eye. New York: Routledge, 1998.

Faris, Wendy B. Ordinary Enchantment: Magical Realism and the Remystification of Narrative. Nashville: Vanderbilt University Press, 2004.

Gürova, Ercan. "Magical and Fantastical Elements in the Incredible and Sad Tale of Innocent Erendira and Her Heartless Grandmother by Marquez" in Journal of Social and Humanities Sciences Research 5.23 (2018): 1209-13

Haraway, Donna. "Situated Knowledges: The Science Question in Feminism and the Privilege of Partial Perspective," in Feminist Studies 14.3 (Fall 1988): 592-93.

Marquez, Gabriel Garcia. The Incredible and Sad Tale of Innocent Erendira and Her Heartless Grandmother in the Norton Introduction to the Short Novel. Ed. Jerome Beaty. New York: Norton \&Company, 1982.

Merchant, Carolyn. The Death of Nature. Women, Ecology and the Scientific Revolution. San Francisco: Harper and Row, 1980.

Puleo , Alicia H. "What is Ecofeminsm?" in Quaderns de la Mediterrània 25(2017): 27-34

Quinn, Edward. A Dictionary of Literary and Thematic Terms. New York: Facts on File, 2006.

Shober, Dianne. "Ecofeminist invitations in the works of Sindiwe Magona" in Literator 38(1), a1392. https://doi. org/10.4102/lit.v38i1.1392. 1/9/2018.

Tanritanir, Bülent Cercis and A. Melike Çalişkan. “Oppressor, Oppressed And Gabriel García Márquez" in The Journal of International Social Research 9.45 (2016): 214-18.

Thamarana, Simhachalam. "Magic Realism in English Literature and Its Significant Contribution" in International Journal of English Language, Literature and Translation Studies. 2.4 (2015): 263-266

Warren, K. Ecofeminist Philosophy: A Western Perspective on What It Is and Why It Matters. New York: Roman and Littlefield, 2000.

Wood, Michael. Gabriel Garcia Marquez: One Hundred Years of Solitude. New York: Cambridge University Press, 1990. 